\title{
Program against Cancer in Congo, Republic
}

El Hadji Seydou Mbaye*

BCNet International Working Group, International Agency for Research on Cancer, World Health Organization, Dakar, Senegal.

*Corresponding Author: El Hadji Seydou Mbaye, BCNet International Working Group, International Agency for Research on Cancer, World Health Organization, Dakar, Senegal.

Received date: February 08, 2021; Accepted date: July 20, 2021; Published date: July 23, 2021

Citation: E Hadji Seydou M. (2021) Program Against Cancer in Congo, Republic. International Journal of Clinical Case Reports and Reviews. 7(5); DOI: $10.31579 / 2690-4861 / 119$

Copyright: () 2021 El Hadji Seydou Mbaye, This is an open-access article distributed under the terms of the Creative Commons Attribution License, which permits unrestricted use, distribution, and reproduction in any medium, provided the original author and source are credited.

\begin{abstract}
Worldwide, one in eight deaths is due to cancer. Projections based on the GLOBOCAN 2012 estimates predict a substantive increase new cancer cases per year by 2035 in developing countries if preventive measures are not widely applied. According to the World Health Organization (WHO), millions of lives could be saved each year if countries made use of existing knowledge and the best cost-effective methods to prevent and treat cancer. Therefore, the aim of this study is to estimate a provisional budget against cancer in low and middle incomes countries, according the GNI-PPP, the cancer incidence and the number of population. Economically country classification is determining with the Gross national income (GNI), per capita, Purchasing power parity (PPP), according the administrations of the International Monetary Fund (IMF), the World Bank (WB) and the Central Intelligence Agency (CIA). Cancer incidence data presented are based on the most recent data available at IARC. However, population compares estimates from the US Bureau of the Census. The provisional budget is establishing among the guidelines developed by WHO for regional and national cancer control programs according to national economic development. Provisional budget against cancer is estimated to 40,331.765 (thousands of U.S \$) for a population of 4,954,674 persons in Congo, Republic.
\end{abstract}

Keywords: cancer program; cancer control; prevention; early detection; institutional reinforcement; diagnosis; treatment; low and middle-income countries; congo, republic

\section{Introduction}

Worldwide, one in eight deaths is due to cancer. Cancer causes more deaths than AIDS, tuberculosis, and malaria combined [1]. When countries are grouped according to economic development, cancer is the leading cause of death in developed countries and the second leading cause of death in developing countries [2]. Rates of cancers common in Western countries will continue to rise in developing countries if preventive measures are not widely applied [3-5]. Projections based on the GLOBOCAN 2012 estimates predict a substantive increase to 19.3 million new cancer cases per year by 2025 , due to growth and ageing of the global population. Incidence has been increasing in most regions of the world, but there are huge inequalities between rich and poor countries. More than half of all cancers (56.8\%) and cancer deaths (64.9\%) in 2012 occurred in less developed regions of the world, and these proportions will increase further by 2025 [6]. By 2030, the global burden is expected to grow to 21.4 million new cancer cases and 13.2 million cancer deaths [7]. Rates of cancers will continue to rise by 2035 with $23,980,858$ new cancer cases [3-5].

In addition to the human toll of cancer, the financial cost of cancer is substantial [8-10]. Cancer has the most devastating economic impact of any cause of death in the world [10]. Data limitations do not allow estimating the worldwide economic costs of cancer. However, portions of the total costs of cancer have been estimated to be as high as $\$ 895$ billion (US) worldwide $[9,10]$. It is estimated that more than half of all cancer cases and deaths worldwide are potentially preventable [3-5, 7].
In Congo Republic, the number of new cancer cases is estimated to 2,327 with 1,571 deaths in 2015 . By 2025 , incidence is expected to grow to 3,204 with 2,154 deaths. Rates of cancers will continue to rise to 4,493 new cancer cases by 2035 with 3,032 deaths if preventive measures are not widely applied [3-5]. According to the World Health Organization (WHO); Entitled: National Cancer Control Programs: Policies and Managerial Guidelines, millions of lives could be saved each year if countries made use of existing knowledge and the best cost-effective methods to prevent and treat cancer [11].

"An urgent need in cancer control today is to develop effective and affordable approaches to the early detection, diagnosis, and treatment of breast cancer among women living in less developed countries," explains Dr Christopher Wild, Director of IARC. "It is critical to bring morbidity and mortality in line with progress made in recent years in more developed parts of the world." [6].

With the data highlighting a large variability of GNI/capita even within similar income levels in the various world regions, it is expected that additional investment in resources and costs may be more dependent on income level of the country than on the GNI group or the geographic region of the world [12]. Therefore, the aim of this study is to estimate a provisional budget against cancer in Congo, Republic, according the GNIPPP, the cancer incidence and the number of population.

\section{Methods}

\section{Economically Country Classification}


The economics states are established among the means of GNI-PPP according the administrations of the International Monetary Fund (IMF); the World Bank (WB) and the Central Intelligence Agency (CIA) [1315]. The difference concerning the same country can be considerable among the data origin. These variations are explaining by:

\section{- $\quad$ GNI-PPP is estimated \\ - $\quad$ Anterior projection of an economic crisis changes GNI-PPP}

data population

The estimation of the population included in the local

- The choice elements for GNI-PPP evaluation have some subjective part.

These data must be taken with precaution

Economically Country is divided according to the gross national income (GNI) per capita 2016, Atlas method and PPP [15].

$\begin{array}{ll}\text { - } & \text { Estimated to be low income }(\$ 1,005 \text { or less) } \\ \text { - } & \text { Estimated to be lower middle income }(\$ 1,006 \text { to } \$ 3,995) \\ \text { - } & \text { Estimated to be upper middle income }(\$ 3,956 \text { to } \$ 12,235) \\ & \text { Estimated to be high income }(\$ 12,236 \text { or more). }\end{array}$

Gross National Income (GNI), Per Capita, Purchasing Power Parity (PPP)

Gross national product is gross domestic product (GDP) plus net income (employee compensation and investment income) from abroad. GNI, per capita is GNI divided by mid-year population.

PPP is purchasing power parity; an international dollar has the same purchasing power over GNI as a U.S. dollar has in the United States. PPP exchange rates are used to account for the local prices of goods and services not traded internationally. However, PPP is used to compare across national accounts, not for making international poverty comparisons [15].

\section{Cancer Incidence}

Incidence is the number of new cases that occurs during a given period of time in a specified population. It can be expressed as an absolute number of cases per year or as a rate per 100,000 persons per year. The rate provides an approximation of the average risk of developing a cancer. Cancer incidence data presented are based on the most recent data available at IARC. GLOBOCAN 2012 provides a global profile of cancer that has been developed using a number of methods that are dependent on the availability and the accuracy of the data. National sources are used where possible, with local data and statistical modeling used in their absence [3-5].

\section{Population}

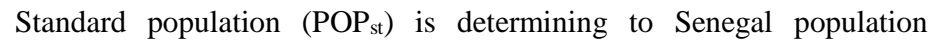
(Western Africa) with $14,668,522$ persons. Congo, Republic population is estimated to $4,954,674$ persons. Population estimates for this country explicitly take into account the effects of excess mortality due to AIDS; this can result in lower life expectancy, higher infant mortality, higher death rates, lower population growth rates, and changes in the distribution of population by age and sex than would otherwise be expected. Population compares estimates from the US Bureau of the Census [16] based on statistics from population censuses, vital statistics registration systems, or sample surveys pertaining to the recent past and on assumptions about future trends: https://www.cia.gov/library/publications/the-world-

factbook/geos/cf.html

\section{Provisional Budget (thousands of U.S \$)}

The World Health Organization (WHO) emphasizes that, when developing national strategies for controlling cancer, countries should consider the following four broad approaches based on their economic development:

$\begin{array}{ll}\text { - } & \text { The primary prevention } \\ \text { - } & \text { The early detection and secondary prevention } \\ \text { - } & \text { The diagnosis and treatment } \\ \text { The palliative care. }\end{array}$

The provisional budget is establishing among the guidelines developed by WHO for regional and national cancer control programs according to national economic development [11]. However, an International Atomic Energy Agency [17] report suggested that in developing countries at least $60 \%$ of cancer patients require radiation treatment.

Radiotherapy is one of the main components of modern cancer treatment and requires substantial capital investment, trained professionals in several disciplines, high precision equipment and a particular external and internal organizational structure. In High Incomes Countries, the healthcare costs can be as much as $8.4 \%$ (UK in 2007) to $18 \%$ (USA in 2009 ) of a country's gross domestic product [18]. Cancer consumes about $5-10 \%$ of the global healthcare budget, of which radiotherapy only consumes about $5 \%[18,19]$; thus, more than $50 \%$ of cancer patients requiring radiotherapy in low and middle-income countries lack access to treatment. A benchmark of between 400 and 500 patients per treatment unit per year has been used to calculate machine throughput in several reports [17, 20-21]. The benchmark of 450 patients per machine, which corresponds to about 8 operating hours per day, seems adequate for High Incomes Countries. For scenarios where radiotherapy demand is not satisfied, a treatment day of $10 \mathrm{~h}$ optimizes the utilization of equipment and decreases the number of machines needed. But, the range of needs currently covered varies from $0 \%$ and $3-4 \%$ in Low Incomes Countries in Latin America and Africa up to 59-79\% in Up-Middle Incomes Countries in Europe-Central and Asia [22].

However, in this study, in order to found the best cost-effective methods to prevent and treat cancer, the number of machines needs is establishing among 3 millions of peoples and not by the number of cancer cases, according to the weakness of the countries incomes.

\section{Standard budget for 5 years (SO)}

Standard budget for 5 years $\left(\mathrm{S}_{0}\right)$ is estimated using a population of

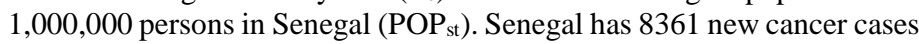
$\left(\mathrm{CI}_{\mathrm{st}}\right)$ in 2015 [3-5] with a means GNI-PPP $\mathrm{st}_{\mathrm{st}}$ of US\$2,551 referred to the year 2016 (low middle income country), according the administrations of the International Monetary Fund (IMF); the World Bank (WB) and the Central Intelligence Agency (CIA) [13-15]. Estimation budget is taken into account the weakness of the countries incomes.

\section{Standardized rapport (RO)}

Standardized rapport $\left(\mathrm{R}_{0}\right)$, among the GNI-PPP, $\mathrm{CI}$ and the number of the population, is calculated. Standardization simplifies comparisons of GNIPPP and cancer incidence rates among populations.

\section{GNI-PPPXCI/POP \\ $\mathbf{R}_{\mathbf{0}}=$ GNI-PPPstXCIst /POPst}

Note:

* For Radiotherapy equipment, $\mathrm{R}_{0}=$ GNI-PPP X POP / GNI-PPPst X 3 million peoples; 
Senegal has installed two new radiotherapy machines in 2017. Radiotherapy equipment is estimated to US\$2,500,000.

${ }^{* *}$ For Prevention and screening infrastructure, $\mathrm{R}_{0}=$ GNI-PPPX POP $/$ GNI-PPPst X 3 million peoples.

$\mathbf{R}_{\mathbf{0}}=$ Standardized rapport among the GNI-PPP, CI and the number of the population

GNI-PPP $_{\text {st }}=$ Standard Gross National Income Per capita Purchasing Power Parity in Senegal

GNI-PPP $=$ Gross National Income Per capita Purchasing Power Parity of interest

$\mathbf{C I}_{\text {st }}=$ Standard Cancer Incidence in Senegal

$\mathbf{C I}=$ Cancer Incidence of interest

$\mathbf{P O P}_{\mathbf{s t}}=$ Standard Population in Senegal

$\mathbf{P O P}=$ Population of interest

\section{Results}

\begin{tabular}{|c|c|c|c|c|c|c|}
\hline \multirow[b]{2}{*}{ Country } & \multicolumn{4}{|c|}{ GNI per capita Purchasing power parity (PPP) } & \multirow[b]{2}{*}{ Population } & \multirow{2}{*}{$\begin{array}{c}\text { Cancer } \\
\text { incidence } \\
(\mathrm{CI})\end{array}$} \\
\hline & Ref. & US\$ & Year & $\begin{array}{c}\text { Means of GNI-PPP } \\
\text { (US\$) }\end{array}$ & & \\
\hline \multirow{3}{*}{ Congo, Rep. } & IMF & 6,939 & 2016 & \multirow{3}{*}{6,343} & \multirow{3}{*}{$4,954,674$} & \multirow{3}{*}{2,327} \\
\hline & WB & 5,390 & 2016 & & & \\
\hline & CIA & 6,700 & 2016 & & & \\
\hline
\end{tabular}

$\mathbf{I M F}=$ International Monetary Fund; WB= World Bank; CIA= Central Intelligence Agency; GNI= Gross National Income; $\mathbf{P P P}=$ Purchasing Power Parity; Ref.= Reference.

Table 1: GNI-PPP, Cancer incidence (CI) and the number of the Population

\begin{tabular}{|c|c|c|c|c|c|}
\hline Cancer Control & Management & $\begin{array}{l}\text { Stand. } \\
\text { budget } \\
\text { (So) }\end{array}$ & $\begin{array}{l}\text { Stand. } \\
\text { rapport } \\
\left(\mathbf{R}_{0}\right)\end{array}$ & $\begin{array}{l}\text { Account } \\
\operatorname{per}\left(\mathbf{R}_{0}\right)\end{array}$ & $\begin{array}{l}\text { General } \\
\text { POP. } \\
\text { budget }\end{array}$ \\
\hline \multirow{8}{*}{$\begin{array}{l}\text { Cancer primary } \\
\text { prevention }\end{array}$} & Development of an information system & 50 & 2.04877 & 102.438 & 507.548 \\
\hline & Against Tobacco & 250 & 2.04877 & 512.192 & $2,537.744$ \\
\hline & Against Infections & 500 & 2.04877 & 1024.385 & $5,075.489$ \\
\hline & Against carcinogenic substances & 125 & 2.04877 & 256.096 & $1,268.872$ \\
\hline & Against environmental risks & 125 & 2.04877 & 256.096 & $1,268.872$ \\
\hline & Diet or nutrition promotion & 250 & 2.04877 & 512.192 & $2,537.744$ \\
\hline & Sport promotion & 200 & 2.04877 & 409.754 & $2,030.195$ \\
\hline & Cancer risk factors survey & 50 & 2.04877 & 102.438 & 507.548 \\
\hline \multirow{5}{*}{$\begin{array}{l}\text { Cancer early } \\
\text { detection and } \\
\text { secondary } \\
\text { prevention. }\end{array}$} & Breast cancer screening & 150 & 2.04877 & 307.315 & $1,522.646$ \\
\hline & Cervical cancer screening & 125 & 2.04877 & 256.096 & $1,268.872$ \\
\hline & Prostate cancer screening & 50 & 2.04877 & 102.438 & 507.548 \\
\hline & Colorectal cancer screening & 50 & 2.04877 & 102.438 & 507.548 \\
\hline & Others cancers screening & 50 & 2.04877 & 102.438 & 507.548 \\
\hline \multirow{3}{*}{$\begin{array}{l}\text { Cancer institutional } \\
\text { reinforcement }\end{array}$} & Rise of cancer professional & 125 & 2.04877 & 256.096 & $1,268.872$ \\
\hline & Development of cancer research & 175 & 2.04877 & 358.534 & $1,776.421$ \\
\hline & Development of cancer prevention courses & 100 & 2.04877 & 204.877 & $1,015.097$ \\
\hline \multirow{5}{*}{$\begin{array}{l}\text { Cancer diagnosis } \\
\text { and treatment }\end{array}$} & Assistance for Palliative Care & 150 & 2.04877 & 307.315 & $1,522.646$ \\
\hline & Chemotherapy equipment & 100 & 2.04877 & 204.877 & $1,015.097$ \\
\hline & Surgical equipment & 175 & 2.04877 & 358.534 & $1,776.421$ \\
\hline & Radiotherapy equipment ${ }^{*}$ & 2,500 & 4.10656 & $10,266.4$ & $10,266.4$ \\
\hline & $\begin{array}{l}\text { Prevention and screening } \\
\text { infrastructure }\end{array}$ & 400 & 4.10656 & $1,642.624$ & $1,642.624$ \\
\hline Total & & 5,700 & & & $40,331.765$ \\
\hline \multicolumn{6}{|c|}{$\begin{array}{l}\text { Based on: World Health Organization. The National Cancer Control Programmes: policies and managerial guidelines. 2nd ed. } \\
\text { Geneva, 2002. }\end{array}$} \\
\hline \multicolumn{6}{|c|}{$\begin{array}{l}\mathbf{S}_{\mathbf{0}}=\text { Standard budget for } 5 \text { years for a population of } 1,000,000 \text { persons; } \mathbf{R}_{\mathbf{0}}=\text { Standardized rapport among the GNI-PPP, CI and the } \\
\text { number of the population; }{ }^{*} \text { Radiotherapy equipment among only } \mathbf{G N I - P P P} / \mathbf{G N I - P P P} \text { st for each } 3 \text { million peoples; }{ }^{* *} \text { Prevention } \\
\text { and screening infrastructure among only GNI-PPP/GNI-PPPst, for each } 3 \text { million peoples. }\end{array}$} \\
\hline
\end{tabular}

Table 2: Estimated Budget (thousands of U.S \$).

\section{Conclusion}

Cancer has the most devastating economic impact of any cause of death in the world. Incidence has been increasing in most regions of the world, but there are huge inequalities between rich and poor countries. Projections based on the GLOBOCAN 2012 estimates predict a substantive increase to millions new cancer cases per year by 2030.
Rates of cancers will continue to rise by 2035 in Congo, Republic, if preventive measures are not widely applied. An urgent need in cancer control today is to develop effective and affordable approaches. It is expected that additional investment in resources and costs may be more dependent on income level of the country than on the GNI group or the geographic region of the world. However, in order to found the best cost- 
effective methods to prevent and treat cancer, provisional budget against cancer is estimated to 40,331.765 (thousands of U.S \$) for a population of 4,954,674 persons in Congo, Republic, according the GNI-PPP, the cancer incidence and the number of population.

It is very important for all organizations to be aware of the complexity of cancer control. A flexible approach is needed. This account must be added to the actual supply efforts of cancer prevention and treatment. However, effective measures to reduce cancer morbidity and mortality require the active participation of cancer survivors and their local communities; the mobilization and appropriate allocation of resources; the formulation of evidence-based policies and proven interventions; and the commitment of organizations and institutions in the nonprofit, for-profit, and governmental sectors. Ultimately, cancer control goes hand in hand with efforts to promote human and economic development and to improve standards of health, education, and medical care throughout the world.

\section{References}

1. World Health Organization. (2007) Ten statistical highlights in global public health. World Health Statistics, Geneva.

2. American Cancer Society (2011) Global Cancer Facts \& Figures 2nd Edition. Atlanta.

3. Ferlay J, Soerjomataram I, Ervik M, Dikshit R, Eser S, et al. (2013). GLOBOCAN 2012 v1.0, Cancer Incidence and Mortality Worldwide: IARC Cancer Base No. 11. Lyon, France: International Agency for Research on Cancer.

4. GLOBOCAN (2012). Cancer Incidence, Mortality and Prevalence Worldwide. World.All cancers excl. non-melanoma skin cancer. Estimated number of new cancers in 2035 (all ages).

5. GLOBOCAN (2012). Cancer Incidence, Mortality and Prevalence Worldwide. All countries. All cancers excl. non-melanoma skin cancer. Estimated number of new cancers in 2015 (all ages).

6. International Agency for Research on Cancer. (2013) PRESS RELEASE $\mathrm{N}^{\circ} 223$. Latest world cancer statistics Global cancer burden rises to 14.1 million new cases in 2012: Marked increase in breast cancers must be addressed; Lyon/Geneva.

7. Ferlay J, Shin HR, Bray F, Forman D, Mathers CD, et al. (2010) GLOBOCAN 2008, Cancer Incidence and Mortality Worldwide: IARC CancerBase No.10. France, Lyon. 127: 2893-2917.
8. Mackay J, Jemal A, Lee NC, Parkin DM (2006) The Cancer Atlas. American Cancer Society; Atlanta.

9. John RM, Ross H (2008) Economic value of disability-adjusted life years lost to cancers.

10. American Cancer Society (2010) American Cancer Society and LIVESTRONG. The Global Economic Cost of Cancer; Atlanta.

11. World Health Organization (2002) The National Cancer Control Programmes: policies and managerial guidelines. 2nd ed. Geneva.

12. Zubizarreta E, Van Dyk J, Lievens Y (2017) Analysis of Global Radiotherapy Needs and Costs by Geographic Region and Income Level. Clinical Oncology 29: 84-92

13. International Monetary Fund - IMF. (2016) World Economic Outlook Database.

14. Central Intelligence Agency - CIA World Factbook. COUNTRY COMPARISON, GDP - PER CAPITA (PPP). 2016.

15. World Bank. (2017) Gross national income per capita 2016, Atlas method and PPP. World Development Indicators database.

16. US Bureau of the Census. (2017) Population compares estimates.

17. International Atomic Energy Agency (2010) Planning National Radiotherapy Services: a Practical Tool. HUMAN HEALTH SERIES No 14: 83.

18. Sullivan R, Peppercorn J, Sikora K, et al. (2011) Delivering affordable cancer care in high-income countries. Lancet Oncol 12: 933-980.

19. Luengo-Fernandez R, Leal J, Gray A, Sullivan R (2013) Economic burden of cancer across the European Union: a population-based cost analysis. Lancet Oncol 14: 1165-1174.

20. Slotman BJ, Cottier B, Bentzen SM, Heeren G, Lievens Y, et al. (2005) Overview of national guidelines for infrastructure and staffing of radiotherapy. ESTRO-QUARTS: work package 1. Radiother Oncol 75:349-354.

21. International Atomic Energy Agency (2008) Setting up a radiotherapy programme: clinical, medical physics, radiation protection and safety aspects. Vienna: International Atomic Energy Agency.

22. Zubizarreta EH, Fidarova E, Healy B, Rosenblatt E (2015) Need for Radiotherapy in Low and Middle-Income Countries. The Silent Crisis Continues. Clinical Oncology 27: 107-114

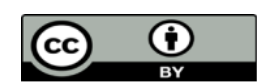

This work is licensed under Creative Commons Attribution 4.0 License
Ready to submit your research? Choose Auctores and benefit from:

*ast, convenient online submission
*igorous peer review by experienced research in your field
*apid publication on acceptance
* authors retain copyrights
* imique DOI for all articles
immediate, unrestricted online access

At Auctores, research is always in progress.

Learn more www.auctoresonline.org/journals/international-journal-ofclinical-case-reports-and-reviews 